\title{
Upaya Meningkatkan Motivasi Dan Hasil Belajar Peserta Didik Pada Pelajaran Matematika Melalui Pembelajaran Tutorial Berbasis Ispring Di Kelas X SMAN 10 Garut
}

\author{
Hikmat Arief ${ }^{1}$, Ecep Andang ${ }^{2}$, Enung Nurjanah ${ }^{3}$, Yuan Risnandah ${ }^{4}$ \\ ${ }^{1234}$ Institut Pendidikan Indonesia GARUT \\ J1. Terusan Pahlawan No.32, RW.01, Sukagalih, Kec. Tarogong Kidul, \\ Kabupaten Garut, Jawa Barat 44151 \\ Email : hikmatasgar@gmail.com, hikmat_arief_mhs@institutpendidikan.ac.id ${ }^{1}$, \\ ecep_andang_mulyana_mhs@institutpendidikan.ac.id ${ }^{2}$ \\ enung@institutPendidikan.ac.id ${ }^{3}$ \\ yuan_risnandah_mhs@institutpendidikan.ac.id ${ }^{4}$
}

\begin{abstract}
Abstrak, Perkembangan tekhnologi dan informasi yang semakin maju membuat teknologi berbasis komputer dapat diaplikasikan dalam dunia pendidikan. Pemanfaatan teknologi komputer dijadikan sebagai media pembelajaran ataupun sumber belajar. Bahkan sudah banyak sumber belajar yang beredar secara online berbentuk e-learning. Untuk memudahkan dalam penyampaian materi pembelajaran, maka materi ini dikemas secara menarik dalam aplikasi yang bersifat mendidik bagi mereka. Tujuan dari penelitian ini adalah untuk membuat suatu pembelajaran online yang bervariasi kepada siswa dengan menggunakan aplikasi pembelajaran berbasis multimedia sebagai sarana untuk mengenalkan Matematika untuk sma dan untuk mengetahui sejauh mana penggunaan Ispring dapat dimanfaatkan dalam pembelajaran Persamaan nilai mutlak pada mata pelajaran Matematika .
\end{abstract}

\section{Kata Kunci: Pembelajaran Tutorial Berbasis Ispring, Motivasi dan Hasil Belajar}

\section{PENDAHULUAN}

Pendidikan merupakan investasi berharga bagi sebuah peradaban, disampin itu pula pendidikan memegang peranan yang sangat vital dalam setiap sektor kehidupan kehidupan. (Pendidikan, Kebudayaan, and Indonesia 2013) Berbagai upaya dilakukan pemerintah dalam meningkatkan kualitas pendidikan nasional, diantaranya pembaharuan kurikulum, peningkatan kualitas tenaga pendidik, penataan manajemen pendidikan serta penerapan teknologi informasi pendidikan.

Dalam pendidikan peranan pembelajaran matematika sangat penting, selain matematika tumbuh dan berkembang untuk dirinya sendiri juga melayani pengetahuan-pengetahuan lain dalam perkembangan dan operasinya (Karunia Eka Lestari \& Mokhammad Ridwan Yudhanegara, n.d.). Kedudukan matematika sebagai "Ratunya Ilmu" menjadikan ilmu-ilmu pengetahuan lain tidak bisa lepas dari matematika. (Pembelajaran et al. 2014)
Perkembangan matematika tidak bergantung terhadap pengetahuan lain, namun sebaliknya pengetahuan lain seperti fisika, kimia, biologi dan ilmu-ilmu lain berkembang dari dasardasar konsep kelimuan matematika.

Proses pembelajaran ini merupakan tanggung jawab guru dalam mengembangkan segala potensi yang ada pada peserta didik. (Rivalina 2014), (Suhana 2009) Tujuan pokok proses pembelajaran adalah untuk mengubah tingkah laku peserta didik berdasarkan tujuan yang telah direncanakan dan disusun oleh guru sebelum proses kegiatan pembelajaran berlangsung. Perubahan tingkah laku itu mencakup aspek intelektual.

(Unesco 2002) Teknologi pendidikan dalam istilah bahasa Inggris disebut dengan "instructional technolgy" atau "Education Technology". Pendidikan semacam ini yang diutamakan ialah media komunikasi yang berkembang secara pesat sekali yang dapat dimanfaatkan dalam pendidikan. Alat - alat teknologi ini lazim disebut "hardware" antara lain berupa TV, radio, video, tape, komputer 
dan lain - lain. Selain dari itu pendidikan juga menggunakan teknologi yang disebut dengan "software" antara lain menganalisa dan mendesain urutan atau langkah-langkah belajar berdasarkan tujuan yang ingin dicapai dengan metode penyajian yang serasi dan penilaian keberhasilannya (Dewi 2016), (Pembelajaran et al. 2014).

(Rusman 2011) menyatakan bahwa Pembelajaran Berbasis Teknologi Informasi dan Komunikasi terbagi menjadi: (1) komputer sebagai media pembelajaran, (2) internet sebagai media pembelajaran. Pembelajaran berbasis TIK biasanya menggunakan perangkat hardware dan software dalam aplikasinya, selain itu juga didukung oleh jaringan internet (Lia 2016), (Muslih 2016).

Ada beberapa langkah yang bisa ditempuh oleh seorang guru baik untuk meningkatkan motivasi peserta didik atau pun untuk meningkatkan hasil belajar peserta didik, yaitu diantaranya mencoba mengubah cara metode mengajar dari metode ceramah ke metode pembelajaran interaktif seperti model tutorial, game's, simulasi atau drill (Muhayat et al. 2017), (Hwang, G. J., \& Chen 2017). Dengan metode interaktif ini diharapkan dapat menigkatkan motivasi dan hasil belajar peserta didik. Dan pada saat ini guru-guru di SMA NEGERI 10 Garut dalam proses belajar mengajar masih menggunakan metode ceramah, jarang sekali guru-guru menggunakan media power point dan LCD projector. Dan dari hasil pengamatan di SMA NEGERI 10 Garut, belum ada guru yang menggunakan media pembelajaran tutorial berbasis ispring.

Penulisan artikel ini dilakukan dengan cara observasi dan studi pustaka yaitu dengan cara menelusuri berbagai arikel ilmiah dan jurnal yang berhubungan dengan "Upaya Meningkatkan Motivasi dan Hasil Belajar Peserta Didik pada Pelajaran Matematika melalui Pembelajaran Tutorial Berbasis Ispring “. Setelah itu penulis menyeleksi dan melakukan pecobaan pada siswa dengan Ispring pada saat Penilaian Akhir Tahun.

\section{KAJIAN TEORI}

\section{a. Persamaan nilai mutlak}

Seorang anak bermain lompat-lompatan di lapangan. Dari posisi diam anak tersebut melompat 5 langkah kedepan, kemudian 7 langkah ke belakang, dilanjutkan 4 langkah ke depan, dan akhirnya 6 langkah kebelakang.(Karunia Eka Lestari \& Mokhammad Ridwan Yudhanegara, n.d.)

\section{Permasalahan:}

1. Dapatkah anda membuat sketsa lompatan anak tersebut?

2. Tentukan langkah posisi akhir anak tersebut!

3. Berapa langkah yang dijalani anak tersebut?

Alternatif penyelesaian

Kita definisikan ke depan adalah searah dengan sumbu $X$ positif dan kebelakang searah dengan sumbu $X$ negatif.

Perhatikan sketsa berikut!

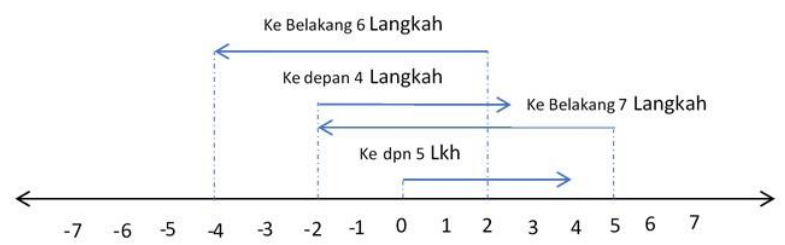

Misalkan $X=0$ adalah posisi awal anak. Anak panah yang pertama diatas bilangan menunjukan langkah pertama anak sejauh 5 langkah ke depan (mengarah ke sumbu Xpositif atau +5 , anak panah kedua menunjukan 7 langkah anak kebelakang (mengarah ke sumbu Xnegatif atau - 7)dari posisi akhir langkah pertama, demikian seterusnya.

Berdasarkan sketsa tersebut dapat dilihat pergerakan akhir anak dari posisi awal adalah 4 langkah kebelakang $(X=5+(-7)+$ $4+(-6)=-4)$. Banyak langkah yang dijalani anak tersebut merupakan konsep nilai mutlak karena banyak langkahnya saja yang di hitng bukan arahnya. Banyak langkah dapat dinyatakan dengan nilai mutlak dari sebuah bilangan bulat.

Banyak langkah tersebut adalah sebagai berikut.

Banyak langkah $=|5|+|-7|+|4|+$ $|-6|=22$ langkah

Nilai mutlak $\mathrm{x}$ akan bernilai positif 
atau nol (Nonnegatif). Secara geometris, nilai mutlak suatu bilangan adalah jarak antara bilangan itu dan nol pada paga garis bilangan rill. Jadi, nilai mutlak suatu bilangan tidak mungkin bernilai negatif, tetapi mungkin saja bernilaii nol.

Berikut adalah contoh percobaan adalah perpindahan posisi pada garis bilangan

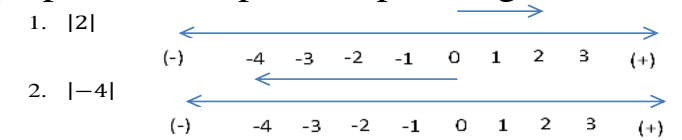

\section{Catatan :}

1. Garis bilangan digunakan sebagai media untuk menunjukan nilai mutak.

2. Tanda panah digunakan untuk menentukan besar nilai mutlak, di mana arah kiri menandakan nilaimutlak dari bilangan negatif dan arah ke kanan menandakan nilai mutlak dari bilangan positif.

3. Besar nilai mutlak dilihat dari panjang anak panah dan dihitung dari bilangan nol. Garis bilangan tersebut dapat dijelaskan sbb:

Garis bilangan 1 : tanda panah bergerak kearah kanan berawal dari bilangan 0 menuju bilangan 2 dan besar langkah yang dilalui tanda panah adalah 2 hal ini berarti nilai $|2|=2$ atau berjarak 2 satuan dari bilangan nol

Garis bilangan 2 : tanda panah bergerak kearah kanan berawal dari bilangan 0 menuju bilangan -4 dan besar langkah yang dilalui tanda panah adalah 4 hal ini berarti nilai $|-4|=4$ atau berjarak 4 satuan dari bilangan nol

Berdasarkan penjelasan diatas, dapat dituliskan konsep nilai mutlak sebagai berikut.

Definisi

Misalkan X bilangan riil, nilai mutlak dari suatu bilangan $\mathrm{X}$ ditulis dengan $|X|$ dan di definisikan:
$|X|=\left\{\begin{array}{l}x, \text { jika } x \geq 0 \\ -x, \text { jika } x<0\end{array}\right.$

Dalam sehari-hari, definisi berikut dapat diungkapkan sebagai berikut.

Nilai mutlak suatu bilangan positif atau nol adalah bilangan itu sendiri, sedangkan nilai mutlak dari suatu bilangan negatif adalah lawan dari bilangan negatif itu.

Berdasarkan defiisi tersebut, terlihat bahwa nilai mutlak suatu bilangan selalu positif atau nol. Bagaimana cara menggambar grafik fungsi nilai mutlak? Berikut akan digambar dari grafik fungsi $\mathrm{f}(\mathrm{x})=$ $\{x$, jika $x \geq 0$

$\{-x$, jika $x<0$

\section{Langkah 1}

Perhatikan langkah-langkah berikut!

Buat tabel untuk menunjukan pasangan beberapa titik yang mewakili grafik tersebut!

\begin{tabular}{|c|c|c|c|c|c|c|c|c|c|c|c|}
\hline $\mathrm{X}$ & -5 & -4 & -3 & -2 & -1 & 0 & 1 & 2 & 3 & 4 & 5 \\
\hline $\begin{array}{l}\mathrm{Y}= \\
\mathrm{f}(\mathrm{x})\end{array}$ & 5 & 4 & 3 & 2 & 1 & 0 & 1 & 2 & 3 & 4 & 5 \\
\hline$(\mathrm{X}, \mathrm{Y})$ & $(-5,5)$ & $(-4,4)$ & $(-3,3)$ & $(-2,2)$ & $(-1,1)$ & $\begin{array}{c}(0, \\
0\end{array}$ & $\begin{array}{c}(1, \\
1)\end{array}$ & $\begin{array}{c}(2, \\
2\end{array}$ & $\begin{array}{c}(3, \\
3)\end{array}$ & $\begin{array}{c}(4, \\
4\end{array}$ & $\begin{array}{c}(5, \\
5\end{array}$ \\
\hline
\end{tabular}

\section{Langkah 2}

Menyajikan titik-titik yang diperoleh pada tabel ke dalam koordinat Cartesius.

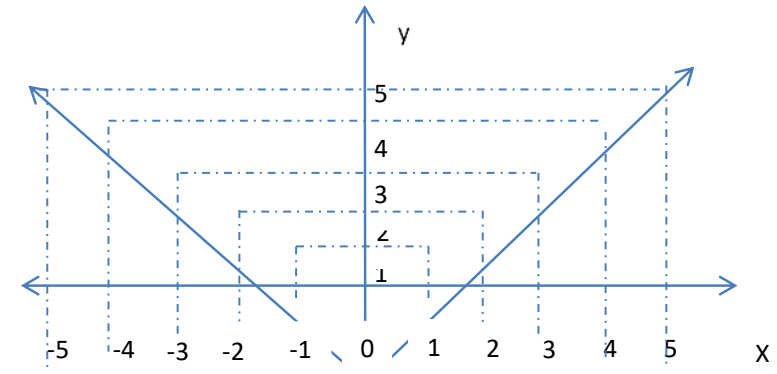

Berdasarkan definisi dan grafik di atas dapat disimpulkan bahwa nilai $|X|$ pada dasarnya menyatakan besar simpangan dari titik $\mathrm{x}=0$

Berdasarkan gambar diatas adakah hubungan antara $\sqrt{X^{2}}$ dan $|X|$ ?

Perhatikan tabel berikut!

\begin{tabular}{|l|l|l|l|l|l|l|l|l|l|l|l|}
\hline $\mathrm{X}$ & -5 & -4 & - & - & - & 0 & 1 & 2 & 3 & 4 & 5 \\
\hline $\mathrm{X}^{2}$ & 2 & 1 & 9 & 4 & 1 & 0 & 1 & 4 & 9 & 1 & 2 \\
& 5 & 6 & & & & & & & & 6 & 5 \\
\hline$\sqrt{X^{2}}$ & 5 & 4 & 3 & 2 & 1 & 0 & 1 & 2 & 3 & 4 & 5 \\
\hline
\end{tabular}




\begin{tabular}{|l|l|l|l|l|l|l|l|l|l|l|l|}
\hline$|X|$ & 5 & 4 & 3 & 2 & 1 & 0 & 1 & 2 & 3 & 4 & 5 \\
Berdasarkan & \multicolumn{1}{c|}{ tabel diatas } \\
Bapat
\end{tabular}
disimpulkan bahwa $|X|=\sqrt{X^{2}}$

\section{b. Powerpoint dan Aplikasi Tambahan Ispring}

Dalam microsoft powerpoint banyak fitur-fitur yang bisa menunjang dalam pembuatan presentasi materi pelajaran ayang akan disamapaikan kepada peserta didik. Adapun beberapa fitur yang ada dalam powerpoint adalah sebagai berikut (Deni. Darmawan 2015) :

1. Mengatur teks

2. Menambah Slide baru

3. Menyimpan dokumen

4. Mengatur Background

5. Menampilkan slide

6. Menyisipkan objek kedalam presentasi

7. Mengatur animasi pada slide

8. Membuat tombol navigasi

Pemberian tombol navigasi ini juga merupakan alternatif untuk menayangkan slide tanpa harus urut nomornya. Tombol navigasi dapat berisi perintah untuk berpindah ke slide tertentu, tak harus satu slide setelahnya atau satu slide sebelumnya.

(Walker 2012) ISpring Presenter merupakan salah satu tool yang mengubah file presentasi menjadi bentuk flash dan bentuk SCORM / AICC, yaitu bentuk yang biasa digunakan dalam pembelajaran dengan e-learning LMS (Learning management System). Perangkat lunak Ispring tersedia dalam versi free (gratis) dan berbayar. Versi free Ispring dapat di download

http://www.ispringfree.com/download.html. (Liu 2019) Ispring Presenter secara mudah dapat diintegrasikan dalam Microsoft powerpoint sehingga penggunaannya tidak membutuhkan keahlian yang rumit. Beberapa fitur Ispring Presenter adalah :

a. Ispring Presenter bekerja sebagai add-ins Powerpoint, untuk menjadikan file Powerpoint lebih menarik dan interaktif berbasis Flash dan dapat dibuka di hampir setiap komputer atau platform.

b. Dikembangkan untuk mendukung $e$ - learning. Ispring Presenter dapat menyisipkan berbagai bentuk media, sehingga media pembelajaran yang dihasilkan akan lebih menarik, diantaranya adalah dapat merekam dan sinkronisasi, video presenter, menambahkan Flash dan video Youtube, mengimpor atau merekam audio, menambahkan informasi pembuat presentasi dan logo perusahaan, serta membuat navigasi dan desain yang unik.(Ensher 2013), (Allen WA 2012), (Greenberg, D. A., \& Zanetis 2012)

c. Mudah didistribusikan dalam format flash, yang dapat digunakan dimanapun dan dioptimalkan untuk web.

d. Membuat kuis dengan berbagai jenis pertanyaan/soal yaitu : True/False, Multiple Choice, Multiple response, Type In, Matching, Sequence, numeric, Fill in the Blank, Multiple Choice Text.

Menu utama yang ada dalam iSpring Presenter pada gambar berikut :

1. Publish yaitu mengatur publikasi presentasi.

Ada 2 cara publikasi presentasi, yaitu

a. Quick Publish yaitu Publikasi ke bentuk flash dengan pengaturan mengikuti default dari program. Caranya yaitu :

1) Isi nama output Flash movie pada field Presentation Title.

2) Tentukan folder lokal atau network share dimana presentasi akan disimpan.

3) Jika sudah selesai, klik tombol publish.

b. Publish yaitu Publikasi dengan pengaturan/setting yang ditentukan sendiri oleh user Publish dengan pengaturan yang ditentukan sendiri oleh user dibagi menjadi beberapa pilihan, yaitu

1) Publish Presentation to my computer yaitu untuk publikasi ke folder pada komputer lokal.

Publish Window tab terdiri dari $4 \mathrm{Tab}$, yaitu

a) General - tujuan adanya komposisi output presentasi flash

b) Settings - tampilan, navigasi,ukuran dan skala untuk output Flash movie. 
c) Media - pilihan kompresi untuk file gambar, audio dan video.

d) SCORM - setting untuk learningcourse.

Sedangkan pada Tab General terdiri dari :

a) Presentation Title yaitu untuk judul presentasi Flash yang akan ditampilkan pada Player.

b) Destination local folder yaitu untuk Folder tempat menyimpan output.

c) File name yaitu untuk Nama output file.swf.

d) Slide Range yaitu untuk menentukan slide yang dipublish semua slide atau hanya slide yang terpilih.

e) Flash Output yaitu untuk mempublish dalam bentuk output flash akan dipublish ke LMS.

2) Publish Presentation to slideboom yaitu publikasi melalui Web/uplode presentasi pada portal online dan menampilkan pada worldwide.

3) Publish Presentation to Web/FTP yaitu menguplode presentasi ke server FTP.

4) Send presentation via E-Mail yaitu mengirim presentasi melalui email.

2. Presentation yaitu pengaturan/manajemen presentasi, presenter, dan tautan/link.

Ada 2 macam presenter yaitu

a. Presenter manager - Presenters Tab.

Pada Presenters Tab kita bisa menambah, mengedit, menghapus presenter atau mengatur presenter yang akan ditambahkan secara otomatis pada presentasi flash. Semua informasi tentang presenter disimpan dalam presentasi, sehingga dapat di edit dalam powerpoint.(Salmilah 2010)

b. Presenter manager - Company Tab Pada Company Tab dapat ditambahkan logo perusahaan dan menge-link ke web site perusahaan

3. Narration yaitu pengaturan narasi video/audio, dan sinkronisasi narasi.

Pada naration terdiri dari :

a. Audio Recording

Berfungsi untuk merekam narasi audio dengan cara membaca teks dengan keras atau narasi lainnya dan mensinkronisasi dengan slideshow.(D Darmawan 2019)

b. Video Recording

Presentasi bisa ditambahkan narasi yang berupa video, menggunakan webcam dan software iSpring Presenter Master Edition.

c. Import Audio

d. Import Video

e. Sinkronisasi

4. Insert yaitu untuk menyisipkan Flash, Quiz, dan video youtube.

a. Menyisipkan Flash

Digunakan untuk menyisipkan external Flash (.swf) movie ke dalam slide Power Point.

b. Menyisipkan Quis

Jendela QuizBuilder ditampilkan sebagai berikut :

1) Bagian Clipboard

Terdiri dari tiga tool standar Copy,Cut dan Paste untuk mengopi, memotong dang menempelkan potongan teks.

2) Bagian Preview

Terdiri dari satu tombol Quiz preview untuk live preview dan melihat kuis sebelum di publish.

3) Bagian Add Question

Menambahkan soal baru ke dalam kuis. Jenis-jenis soal yang bisa dibuat :

a) True/False untuk membuat statemen benar atau salah.

b) Multiple Choice untuk membuat beberapa alternatif jawaban, dengan satu jawaban yang benar.

c) Multiple Response untuk membuat beberapa alternatif jawaban, dengan beberapa jawaban yang benar.

d) Fill in the Blank untuk membuat pertanyaan yang memerlukan jawaban singkat dalam area yang disediakan. Jawaban benar(kunci jawaban) yang disediakan bisa beberapa alternatif/lebih dari satu.

e) Matching untuk membuat soal menjodohkan

c. Menyisipkan Video Youtube 
5. About yaitu untuk info tentang sofware, bantuan, dan update software.

\section{METODE PENELITIAN}

Metode Penelitian yang digunakan dalam penelitian ini adalah metode penelitian eksperimen dengan pendekatan kuantitatif . Bentuk metode eksperimen yang digunakan adalah menggunakan dua sampel yang saling berkorelasi (paired) yaitu sebuah sampel dengan subjek yang sama, namun mengalami dua perlakuan atau pengukuran yang berbeda (Sundayana, n.d.)

Adapun desain penelitian tersebut adalah sebagai berikut:

Tabel 3.1 Desain Penelitian (Sugiyono, 2011:112)

\begin{tabular}{|l|l|l|l|}
\hline Kelompok & Pretest & Perlakuan & Postest \\
\hline KE & $\mathrm{O}_{1}$ & $\mathrm{X}$ & $\mathrm{O}_{2}$ \\
\hline
\end{tabular}

Keterangan:

KE : Kelompok Eksperimen. $\mathrm{X}$

Perlakuan berupa pembelajaran menggunakan pembelajaran tutorial berbasis ispring

$\mathrm{O}_{1} \quad$ : Hasil sebelum pembelajaran menggunakan pembelajaran tutorial berbasis ispring

$\mathrm{O}_{2} \quad$ Hasil setelah pembelajaran menggunakan pembelajaran tutorial berbasis ispring

\section{Pembahasan}

(Arsyad 1997), (Halili, S. H., Razak, R. A., \& Zainuddin 2015) berpendapat bahwa model tutorial merupakan program pembelajaran yang digunakan dalam proses pembelajaran dengan menggunakan perangkat lunak berupa program komputer yang berisi materi pelajaran. Sedangkan menurut (Muslih 2016), (Mugara 2011) bahwa tutorial adalah pembelajaran khusus dengan inkonstruksi yang terkualifikasi dan penggunaan mikrokomputer untuk tutorial secara khusus telah mencukupi. Tutorial dengan metode alternatif diantaranya bacaan, demontrasi, penentuan bacaan atau pengalaman yang membutuhkan respon secara oral dan tulisan, serta adanya ujian. Sebagaimana telah kita ketahui bersama bahwa pembelajaran tutorial bertujuan untuk memberikan "keputusan"/ pemahaman secara tuntas (mastery) kepada peserta didik mengenai materi atau bahan pelajaran yang sedang dipelajari.

1. Perbedaan Hasil Belajar Sebelum dan Setelah Pembelajaran Tutorial Berbasis Ispring.

Perbedaan hasil belajar dapat dibuktikan dengan hasil pengujian hipotesis perbedaan hasil belajar sebelum dan sesudah pembelajaran tutorial berbasis ispring dengan uji Wilcoxon yaitu "Terdapat perbedaan hasil belajar peserta didik sebelum dan sesudah pembelajaran tutorial berbasis ispring pada pelajaran Matematika".

(hamzah 2008) Pada hasil penelitian terdapat perbedaan hasil belajar sebelum peserta didik mendapatkan pembelajaran tutorial berbasis ispring, dimana dari hasil perhitungan statistik hasil pretest dan posttest, untuk data pretest dengan bentuk soal objektef skor rata-rata test 45,4 dengan jumlah data 40 , standar deviasi 10,77 dan standar error mean 1,70 sedangkan untuk data posttest dengan bentuk soal objektif skor rata-rata test 86,83 jumlah data 40 dengan standar deviasi 7,66 dan standar error mean 1,21.

2. Peningkatan Hasil Belajar Setelah Pembelajaran Tutorial Berbasis Ispring.

Perbedaan hasil belajar tersebut yaitu pada hasil belajar sesudah diberikan pembelajaran tutorial berbasis ispring lebih tinggi dibandingkan dengan skor hasil belajar sebelum pembelajaran. Dan perbedaan skor tersebut petanda adanya peningkatan hasil belajar. Adapun peningkatan hasil belajar mekanika teknik dengan pembelajaran tutorial berbasis ispring berada pada kategori tinggi, ini terbukti pada uji hipotesis peningkatan hasil belajar setelah pembelajaran tutorial berbasis ispring dengan uji $t$ yaitu "Terdapat peningkatan hasil belajar peserta didik dalam pembelajaran matematika melalui pembelajaran tutorial berbasis ispring ".

Peningkatan ini terbukti dari skor rata-rata awal materi persamaan nilai 
mutlak pada pelajaran matematika adalah 45,4 atau $45,4 \%$ dari skor ideal 100. Skor tersebut berarti kurang dari kriteria ketuntasan minimal pelajaran matematika yaitu 75 , dan test akhir 86,83 atau $86,83 \%$ dari skor ideal 100 yang artinya lebih besar dari kriteria ketuntasan minimal pelajaran matematika yaitu 75. Dari data tersebut terlihat bahwa, setelah kegiatan pembelajaran dilakukan, secara umum terjadi peningkatan hasil belajar rata-rata sebesar 41,43 atau sekitar 41\%.

3. Peningkatan Motivasi Belajar Setelah Pembelajaran Tutorial Berbasis Ispring

Untuk peningkatan motivasi belajar peserta didik setelah mendapatkan pembelajaran tutorial berbasis ispring, motivasi peserta didik meningkat sangat signifikan. (Sundayana, n.d.) Hal ini dibuktikan dengan pengujian hipotesis peningkatan motivasi belajar peserta didik dimana hasil pengujiannya "Terdapat peningkatan motivasi belajar setelah peserta didik memperoleh pembelajaran tutorial berbasis ispring pada pelajaran mekanika teknik".

Dari hasil perhitungan statistik perbedaan hasil pretest dan posttest motivasi belajar, untuk data motivasi awal dengan bentuk angket skor rata-rata 39,50 dengan jumlah data 40, standar deviasi 3,367 dan standar error mean 0,53 sedangkan untuk data motivasi akhir dengan bentuk angket skor rata-rata 55,8 jumlah data 40 dengan standar deviasi 2,21 dan standar error mean 0,349.

Berdasarkan data di atas terlihat skor angket rata-rata awal pelajaran mekanika teknik adalah 39,50 atau $65,83 \%$ dari skor ideal 60. Dari data tersebut terlihat bahwa, setelah kegiatan pembelajaran dilakukan, secara umum terjadi peningkatan motivasi belajar rata-rata sebesar 16,3 atau sekitar $27,17 \%$.

\section{KESIMPULAN}

Berdasarkan pada hasil penelitian analisis data dan pembahasan yang telah dilakukan, maka peneliti dapat mengambil kesimpulan sebagai berikut:
1. Terdapat perbedaan hasil belajar peserta didik sebelum dan sesudah pembelajaran tutorial berbasis ispring pada pelajaran Matematika, maka terbukti bahwa pembelajaran tutorial berbasis ispring dapat memberikan perubahan skor yang positif dari hasil belajar sebelum diberikannya pembelajaran ke skor hasil belajar sesudah diberikan pembelajaran.

2. Pembelajaran tutorial berbasis ispring dapat meningkatkan hasil belajar peserta didik pada pelajaran Matematika. Hal tersebut didasarkan pada meningkatnya skor hasil belajar peserta didik setelah diberikan pembelajaran tutorial berbasis ispring dan peningkatan hasil belajarnya ada pada kategori tinggi.

3. Pembelajaran tutorial berbasis ispring dapat meningkatkan motivasi belajar peserta didik pada pelajaran Matematika. Hal ini didasarkan pada meningkatnya skor motivasi belajar peserta didik setelah diberikan pembelajaran tutorial berbasis ispring dan peningkatan motivasi belajarnya ada pada kategori tinggi.

4. Terdapat perbedaan motivasi belajar peserta didik sebelum dan sesudah pembelajaran tutorial berbasis ispring pada pelajaran Matematika. Hal ini berarti ketika sesudah diberikannya perlakuan dapat merubah motivasi awal sebelum pembelajaran dengan motivasi akhir setelah pembelajaran.

\section{DAFTAR PUSTAKA}

Allen WA, Smith AR. 2012. "Effects of Video Podcasting on Psychomotor and Cognitive Performance, Attitudes and Study Behavior of Student Physical Therapists." 49: 401-414.

Arsyad, Azhar. 1997. Media Pembelajaran. Jakarta: Raja Grafindo Persada.

Darmawan, D. 2019. "Digital Media Communication Through Multilog Record Relevision (MRT) for Learning Content," 2019.

Darmawan, Deni. 2015. Komunikasi Pendidikan Perspektif BioKomunikasi. Bandung: Remaja 
Rosdakarya.

Dewi, Sinta Verawati. 2016. "Efektivitas Penggunaan Media Screencast OMatic Pada Mata Kuliah Kalkulus Integral Terhadap Hasil Belajar Mahasiswa." Jurnal Penelitian Pendidikan Dan Pengajaran Matematika 2 (1): 61-66.

Ensher, Ellen A. 2013. "E-Mentoring as a Critical E-Learning Approach: The Impact of Social Presence on EMentoring." Communications and Network $05 \quad$ (03): 1-3. https://doi.org/10.4236/cn.2013.53b1 001.

Greenberg, D. A., \& Zanetis, J. 2012. The Impact of Broadcast and Streeming Video and Education. Cissco: Wein Reserach.

Halili, S. H., Razak, R. A., \& Zainuddin, Z. (2015). 2015. "Exploring the Use of 'Wiggio'to Support Online Collaborative Learning for Adult Learners. In Economics, Social Sciences and Information Management: Proceedings of the 2015 International Congress on Economics, Social Sciences and Information Management (IC." Biomass Chem Eng 49 (23-6): 2334.

http://www.ti.com/lit/ds/symlink/cc2 538.html.

hamzah, b. 2008. Model Pembelajaran Menciptakan Mroses Belajar Mengajar Yang Kreatif Dan Efektif. Jakarta. bumi aksara.

Hwang, G. J., \& Chen, C. H. (2017). 2017. "Influences of an Inquiry Based Ubiquitous Gaming Design on Students' Learning Achievements, Motivation, Behavioral Patterns, and Tendency towards Critical Thinking and Problemsolving. British Journal of Educational Technology,.” 信阳 师范学院 1 (1): 287-95. https://doi.org/10.1016/j.sbspro.2015 .04.758.

Karunia Eka Lestari \& Mokhammad Ridwan
Yudhanegara. n.d. Penelitian Pendidikan Matematika. Bandung: Penerbit Refika Adhitama.

Lia, Linda. 2016. "Multimedia Interaktif Sebagai Salah Satu Alternatif Pembelajaran Dalam Bidang Pendidikan Sains." Jurnal Inovasi Dan Pembelajaran Fisika 2 (2): 132-40.

Liu, Fei. 2019. "Construction of the Teaching Model of Second Classroom of Translation Based on Network Platform." Open Journal of Social Sciences 07 (02): 167-77. https://doi.org/10.4236/jss.2019.7201 4.

Mugara, R. 2011. "Meningkatkan Kompetensi Guru Melalui Penguasaan Teknologi Informasi Dan Komunikasi (TIK)." Prodi Pengembangan Kurikulum. Universitas Pendidikan Indonesia. Sunan Kalijaga:Yogyakarta., 2011.

Muhayat, Urip, Wiji Wahyudi, Hari Wibawanto, and Wahyu Hardyanto. 2017. "Pengembangan Media Edukatif Berbasis Augmented Reality Untuk Desain Interior Dan Eksterior." Innovative Journal of Curriculum and Educational Technology 6 (2): 39-48. https://doi.org/10.15294/ijcet.v6i2.19 337.

Muslih, Muslih. 2016. "Pemanfaatan Media Pembelajaran Berbasis ICT Pada Lembaga Pendidikan Non-Formal TPQ." Dimas: Jurnal Pemikiran Agama Untuk Pemberdayaan 16 (2): 215.

https://doi.org/10.21580/dms.2016.1 62.1090.

Pembelajaran, Efektifitas, Matematika Dengan, Model Kooperatif, Team Accelerated, Instruction Berbantuan, C D Interaktif, Bangun Ruang, and Sisi Datar. 2014. "Efektifitas Pembelajaran Matematika Dengan Model Kooperatif Team Accelerated Instruction Berbantuan Cd Interaktif Materi Bangun Ruang Sisi Datar 
Kelas."

Pendidikan, Menteri, D A N Kebudayaan, and Republik Indonesia. 2013. "Menteri Pendidikan Dan Kebudayaan Republik Indonesia," 2013-15.

Rivalina, R. 2014. "Kompetensi Teknologi Informasi Dan Komunikasi Guru Dalam Peningkatan Kualitas Pembelajaran." Jurnal Teknodik 18: 165-176.

Rusman, Dkk. 2011. Pembelajaran Berbasis Teknologi Informasi Dan Komunikasi. jakarta: PT Raja Grafindo Persada.

Salmilah, HJ. 2010. "MODEL PEMBELAJARAN INOVATIF BERBASIS ICT (INFORMATION COMMUNICATION

TECHNOLOGY) Oleh: $\mathrm{Hj}$. Salmilah, S.Kom * Abstrak:" Ulul Albab 12 (2): 10-25.

Suhana, Nanang Hanafiah \& Cucu. 2009. Konsep Strategi Pembelajaran. T 371.1 Ha. Bandung: Refika Aditama.

Sundayana, R. (2014). n.d. Statistika Penelitian Pendidikan. Bandung: Alfabeta.

Unesco. 2002. Teknologi Komunikasi Dan Informasi Dalam Pendidikan: Kurikulum Dan Untuk Sekolah Dan Program Pengembangan Guru. Alih Bahasa Rusli. Gaung Persada Press.

Walker, Dawn-Marie. 2012. "Classroom Assessment Techniques: An Assessment and Student Evaluation Method." Creative Education 03 (06): https://doi.org/10.4236/ce.2012.3261 36. 